Available online at GSC Online Press Directory

GSC Advanced Research and Reviews e-ISSN: 2582-4597, CODEN (USA): GARRC2

Journal homepage: https://www.gsconlinepress.com/journals/gscarr

(REVIEW ARTICLE)

\title{
The role of multi-parametric magnetic resonance imaging (MRI) in early prediction of malignant transformation of low-grade Gliomas (A Systematic review)
}

\author{
Mohammed Danfulani ${ }^{1,{ }^{*}}$ and Shamsuddeen Ahmad Aliyu ${ }^{2}$ \\ ${ }^{1}$ Department of Radiology, Faculty of Clinical Sciences, Usmanu Danfodiyo University Sokoto, Nigeria. \\ ${ }^{2}$ Department of Radiology, Faculty of Clinical Sciences, Usmanu Danfodiyo University Sokoto, Nigeria.
}

Publication history: Received on 28 November 2020; revised on 08 December 2020; accepted on 10 December 2020

Article DOI: https://doi.org/10.30574/gscarr.2020.5.3.0122

\begin{abstract}
Introduction: Low-grade gliomas is the most common primary brain tumour, although the presentation may take up to two decades, there is high tendency of early malignant transformation which raise a growing concern. Multiparametric MRI studies have the potential for predicting the early malignant transformation.

Methods: A comprehensive electronic search of various databases was conducted together with forward tracking of the reference list to retrieve relevant qualitative primary studies. Moreover, hand search for journal that was not available electronically was also conducted. Through assessment of the relevant studies was ensured and the included studies were carefully selected. The relevant data was extracted by data extraction form recommended by Cochrane collaborations.

Results: The search yielded 1158 which was narrowed down to eight (8) studies that satisfied the inclusion criteria. These studies are assessing the role of different MRI parameters in predicting the early malignant transformation of Low-grade gliomas. The risk of bias and the applicability concern of the included studies are low.

Conclusion: Based on the findings of this review; Multi-parametric MRI studies have the potential of predicting the early malignant transformation of low-grade gliomas. There is need for high quality large scale, prospective studies on the role of multi-parametric MRI studies in early prediction of malignant transformation of LGGs and meta-analysis of these studies is highly recommended.
\end{abstract}

Keywords: Magnetic resonance imaging (MRI); Low-grade gliomas (LGGs); Histology, Biopsy; Immunohistochemistry

\section{Introduction}

Central Nervous system (CNS) compromises of two different groups of cells; neural cell and glial cell otherwise called supporting cells [1]. The glial cells are responsible for providing control of the neural cells' environment; they are also involve in repair and isolating the neuronal process [2]. They are grouped into three (3) different categories: astrocytes, or astroglia; oligodendrocytes, or oligodendroglia; and microglia cells, or microglia [2] with each category specialized in certain function [2].

The tumour of the CNS are divided based on their cells of origin and are also graded based on the histo-pathological findings [1].

\footnotetext{
${ }^{*}$ Corresponding author: Mohammed Danfulani

Department of Radiology, Faculty of Clinical Sciences, Usmanu Danfodiyo University Sokoto, Nigeria.
} 


\subsection{Target condition being diagnosed}

According to [3], Gliomas happens to be the most common primary brain tumours. Gliomas comprises of heterogeneous groups of tumours of glial origin within the cerebral cortex, brainstem and the spinal cord, these tumours have different characteristics, growth patent and treatment response [1]. Gliomas have unknown aetiology; however, the increase incidence is associated with a number of genetic disorders, such as; tuberous sclerosis and neurofibromatosis type 1 [3, 4]. Recent studies, indicates that neural stem cells are also associated with the increase incidence of Gliomas [5]

Histology and immunohistochemistry are the gold standard in the diagnosis and grading of glial tumours (tumours originating from glial cells). However, radiological examination such as Computer Tomography (CT) and Magnetic resonance imaging (MRI) plays a significant role [1]. According to World Health Organization (WHO) Gliomas has been divided into those tumours that diffusedly infiltrated the surrounding brain tissues and those that are circumscribed within the brain tissues [6]. The growth rate of diffusedly infiltrating gliomas is faster and therefore has more tendency to progress from low-grade to high-grade [6], while the circumscribed gliomas in the other hand is slower and are generally associated with young age [6]. WHO have provided a provisional grading system of low-grade and high-grade $[1,6]$. This grading system is only based on the aggressiveness rather than the tumour cell type. The incidence of lowgrade gliomas (LGGs) is difficult to find as the International Classification of Diseases for Oncology (ICDO)-3 has not yet identified separate histology code for it [1]. The maximum survival rate of Patients with LGGs may be up to 16.7 year; the tumours may remain stable or may continuously grow [7]. However, there is a tendency for some of these tumours to transform to high-grade gliomas [8].

Surgical resection, Radiotherapy and Chemotherapy are the treatment options, however, there are many factors associated with the choice of treatment $[1,9]$, such as, the age, performance status, tumour locations and the patient's preference [1].There is controversy related to the optimal management of LGGs, as most patients are young with little or no clinical symptoms $[8,9]$. There are arguments on the best time and treatment options for the patients; early aggressive treatment or too little late treatment [1]. The "wait and see" police is mainly based on the assumption that, the tumour size may remain unchanged for a considerable long period of time [10]. Surgical resection is influenced by the tumour location, as resection of tumour located within certain aliquant brain areas may lead to permanent neurological damage, therefore these tumours are non-resect able [1]. The benefit of extensive surgical resection over partial resection has been reported $[9,11]$. Moreover, with the improvement of intra-operative MRI, intra-operative neurological damage has been minimized [9]. A careful selection of time to commence radiation therapy is paramount, moreover, tumour control and radiation toxicity should be carefully assessed [9, 13]. The role of Chemotherapy following surgery and Radiotherapy has been established $[13,12]$. Recently, the benefit of neo-adjuvant Chemotherapy followed by surgical resection has been evaluated, with significant improvement on patients' quality of life [14]. Temozolomide as initial single therapy for LGGs (Oligodendrogliomas) has also been evaluated and significant response has been recorded [13]. Seizures are the common clinical presentation, which occurs in $>90 \%$ of patients and maybe partial or generalized $[12,15]$. Antiepileptic is beneficial in patients with the history of seizure but surgery is the main stay treatment to provide tissues for histology examinations $[12,15]$.

\section{$1.2 \quad$ Index test (s)}

Magnetic resonance imaging is a useful imaging tool in the diagnosis of LGGs, its usefulness has been established in areas such as; image-guided biopsy, surgical resection (intra-operative MRI), radiotherapy planning and treatment response monitoring [5]. There are many different techniques that have an established use in Gliomas imaging, these includes; MRI standard sequences (T1 and T2 weighted), Dynamic susceptibility contrast MRI, Diffusion-weighted MRI, different Perfusion MRI studies (Dynamic Susceptibility Contrast-Enhanced Perfusion MRI and Dynamic ContrastEnhanced Perfusion MRI), Molecular MRI and MRI spectroscopy [5, 16, 17, 18].Combined Gradient-Echo and Spin-Echo imaging have the potential in providing information that may aids better lesion characterization and treatment optimization, this will go a long way in influencing the overall patients' outcome [18]. It has been found out that, the presence of an elevated level of choline and decrease level of $\mathrm{N}$-acetyl aspartate measured in magnetic resonance spectroscopy present a high sensitivity and specificity in differentiating malignant and non-malignant gliomas [19, 20]. In perfusion-weighted magnetic resonance imaging, relative cerebral blood volume (rCBV) has been found to be more accurate than histologic grading in predicting the chances of recurrence in LGGs, particularly in astrocytomas [21].

\subsection{Rationale}

The ability of low-grade gliomas to transform to a more dangerous high-grade tumour raised a serious concern [22]. These transformations negatively affect the overall survival rate of the gliomas' patients [23]. It has been reported that 
monitoring tumour volume over the course of 6 month provides the best prediction of the time of transformation [10, 7]. Diffusion-weighted Imaging (DWI) has also been used to measure the cellularity of the glial tumour and low apparent diffusion coefficient (ADC) has been found to suggest high-grade gliomas [5]. Furthermore, another study suggested that, monitoring angiogenic characteristics of gliomas could influence the physicians in treatment optimization, lesions' categorization and improvement of the overall patients' care [18]. The relationship between combined gradient-echo (GE) and spin-echo (SE) MR imaging (by assessing the blood volume and vascular morphologic parameters) and tumour grade has been assessed and the study identified a significant correlation between GE rCBV and tumour grade. Tumour region with aggressive growth has been identified by multivoxel MR spectroscopy [20]. Moreover, it has been reported that, the early prediction of high-grade transformation will influence accurate treatment majors and subsequently improve survival rate $[5,23,21]$. Additionally, it has also been proposed that, monitoring of low-grade gliomas with MRI parameters before and during treatment will help in early prediction of high-grade transformation [5, 21]. Based on these findings, MRI has the potential of revolutionizing the management approach of gliomas. It may eliminate the controversy surrounding the choice of the best treatment option as well as the best time to commence the treatment of gliomas $[9,14]$. There are many adverse effect as a result of long term treatment, such as; radiation-necrosis and dementia [15], these could be minimized following serial MRI studies suggesting its' low risk of malignant transformation. In the event that, the MRI findings suggested aggressive behaviours in LGGs that is consistent with malignant transformation, early and appropriate treatment majors can be taken. The aims of this review is to search for qualitative studies of diagnostic roles of multi-parametric MRI in the early prediction of high-grade transformation of LGGs. Meta-analysis will be used in order to improve the precision of this review as most studies are likely to be small. When this review confirmed the accuracy and the effectiveness of different MRI parameters in predicting the early malignant transformation of LGGs, then MRI study may stands the chance of being the imaging tool of choice in LGGs.

\section{Objectives}

To assess the role of multi-parametric MRI in the early prediction of high-grade transformation of low-grade gliomas

\section{Methods}

\subsection{Criteria for considering studies for this review}

All studies considered in this review are of English language, no translation was needed, studies are considered to be relevant if its main target was to investigate the correlation of MRI parameter (s) with detection of the malignant progression of LGGs. The participants were defined as those patients with clinical diagnosis of LGGs (untreated or treated with any of the treatment model) who were confirmed with histology or immunohistochemistry.

Plan was made to contact the study authors for further details, if one of the following included in the study:

\subsection{Methodological variables}

- Time interval from reference standard to MRI study

- Evidence of blinding of reporters' findings (MRI studies and reference standard)

\section{$2.3 \quad$ Imaging reporting}

- Single, double, consensus reporting

- Experience of reporter(s)

Studies that did not focus on the role of MRI study in predicting the transformational changes in LGGs were excluded. In the case of multiple publications by the same author or group of authors with similar data, the most recent or complete study were included.

\subsection{Participants}

All patients with the histological diagnosis of LGGs was included, both adult and paediatric population were included and sex differences were not considered, as the LGGs does not vary with sex.

\section{$2.5 \quad$ Index test}

The index test was any MRI study or combination of MRI studies that has established a role in this respect. 


\subsection{Target conditions}

The target condition was the histological diagnosis of LGGs.

\section{$2.7 \quad$ Reference standards}

The reference standard was the diagnosis of LGGs by histology and Immunohistochemistry.

\subsection{Search methods for identification of studies}

\subsubsection{Electronic searches}

In June 2014, a thorough literature search was conducted in various databases to identify relevant studies. Different types of search strategies were used to identify relevant information that could be included in this review.

Ovid MEDLINE and Ovid EMBASE were searched according to the search strategies described in Appendix 1 and Appendix 2. The studies were restricted to 11 years (2003 to 2014), but there was no language restriction. Other search engines such as: MEDION (www.mediondatabase.nl/) using the 'Systematic Reviews and Diagnostic Studies' search filters, the Database of Abstracts of Reviews of Effects (DARE) (www.crd.york.ac.uk/crdweb/), and Health Technology Assessment Database (HTA) have also been searched. Search was also made on clinical guidelines. Cited reference was searched for tracking of the relevant articles on Google Scholar (http://scholar.google.com/).

\subsection{Data collection, analysis and Selection of studies}

Studies identified by the search strategy were initially assessed, based on title and abstract. The full text of the Potential relevant studies was retrieved, reviewed and carefully assessed. Software (review manager) for systematic review recommended by the Cochrane collaboration [26] was used to analyse the studies. Studies that did not meet the inclusion criteria were excluded, and copies of the full text of potentially relevant references were obtained and documented, study selection were presented in a detailed flow chart (Fig 1).

\subsection{Data extraction and management}

The available data was collected by using data extraction form recommended by Cochrane collaborations [27] and when necessary, a request for additional information were sent to study author(s). Study that reported insufficient data for construction of two-by-two tables were also considered due to lack of significant number of studies. The following data were retrieved:

- General information: title, journal, year, publication status, period of study, primary objectives and study design (i.e. prospective and retrospective)

- Sample size: The number of participants meeting the inclusion criteria

- Target condition as reported

- Duration of the study

- Index test: The description of the technique

- Measured MRI parameter(s)

- Main predictor of Malignant transformation

- Reference standard test: description of technique

- Sensitivity of the index test.

- Specificity of the index test

- $\quad$ Number of true positives (TP), true negatives (TN), false positives (FP) and false negatives (FN).

\subsection{Assessment of methodological quality}

The methodological quality of the included studies was assessed by using a modified version of the quality assessment of diagnostic accuracy studies(QUADAS) checklist [28], following the guidelines provided by in chapter 9 of Diagnostic Teat Accuracy [29]. Appendix 2 explains how the QUADAS items for assessing the included studies were applied.

\subsection{Statistical analysis and data synthesis}


Indices for diagnostic performance has been extracted from the data, but due to the fewer number of included studies and missing data from some of the included studies a two-by-two contingency table could not be constructed. Therefore, the data has to be presented qualitatively.

\section{Results}

\subsection{Results of the search}

Ovid MEDLINE, Ovid EMBASE, MEDION, DARE Database of Abstracts of Reviews of Effects (DARE) and Health Technology Assessment Database (HTA) have yielded 1158 results. 177 have been found to be relevance to this review. 169 studies have been excluded (Figure 1), most of them do not satisfied the review question. Eight (8) Studies with 313 participants satisfied the inclusion criteria.

The role of Multiparametric Magnetic Resonance Imaging (MRI) in early prediction. 16 Sep-2014

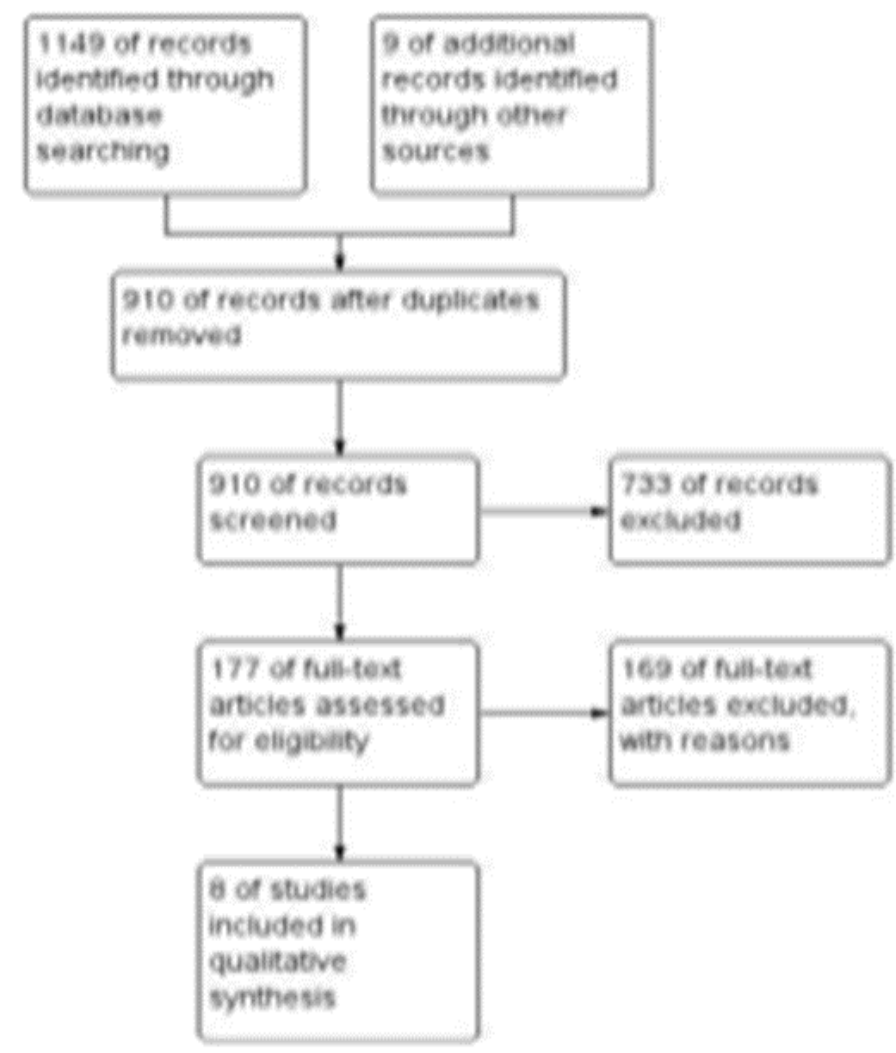

Figure 1 Flow Chart

In addition to the main search, a hand search identified nine (9) studies. Eight (8) studies are relevant to the review but do not satisfy the inclusion criteria. The reasons for exclusion are related to the fact that some of the studies are not particularly concern with the role of MRI in detecting transformational changes, where as other studies are not primary studies. Only one study [24] satisfied the inclusion criteria. The final included studies are Eight (8). Five (5) of them are prospective studies with 131 participants and the remaining three (3) studies are retrospective with 285 participants, and only one study [30] has not reported the duration of their study. Different MRI techniques were used to evaluate the role of MRI in detecting early malignant transformation of LGGs. Three studies [30, 22, 7] used combined MRI techniques; Conventional and Dynamic susceptibility Contrast enhance MRI, another two studies; [10, 31] uses only the conventional MRI sequences. One study [32] used a combination of conventional MRI Techniques; perfusion-weighted and diffusion-weighted imaging. In [33], a combination of conventional, perfusion, and spectroscopy MRI imaging have been used and only Magnetic Resonance Spectroscopy has been used in [34]. It has been reported in [7] that, there is negative association between $\mathrm{rCBV}$ and the time of malignant progression with $(\mathrm{p}=0.0059)$, Transformers have high baseline $\operatorname{rCBV}(\geq 1.75)$ than Non-transformers $(<1.75)$. This relationship is consistent with the report in $[30,32,22,10]$. The tumour volume is reported to be smaller in non-transformers than the transformers [31], in Nine (9) Nontransformers (57 ml, 95\% CI 35-80 ml) and in eighteen (18) Transformers (83 ml, 95\% CI 70-96 ml) (p=0.03) [31]. The 
same study indicated that there is also slower annual growth rate in non-transformers than transformers. Choline/Creatine (Cho/Cr) has been reported to be a significant predictive indicator of malignant transformation in a study done by [33]

\subsection{Description of the included studies}

Mandonnet et al., 2003a [24], this is a retrospective study of 27 patients with untreated LGGs, confirmed by histology; the patients underwent MR imaging to study the kinetics of tumour growth before malignant transformation. The study discovered that: In untreated LGGs, there is continuous linear tumours' growth rate of $3.8-4.4 \mathrm{~mm} / \mathrm{year}$ during the premalignant period. This discovery will go a long way in prompting the choice of early and appropriate treatment, contrary to the idea of "wait and see" mainly based on the assumption that the tumour size may remain stable for a considerable long period of time.

Law et al., 2006 [30], this is also a retrospective study of 189 patients with histologically diagnosed LGGs, all of the patients underwent dynamic susceptibility Contrast-enhanced perfusion MR. The association of baseline relative Cerebral Blood Volume (rCBV) and time of malignant progression were assessed. According to this report, "Lesions with low baseline rCBV had stable tumour volumes at follow-up over time, whereas those with high baseline rCBV (>1.75) had progressively increasing tumour volumes over time". These findings are highly valuable in making a clinical decision on patients' treatment options.

Alimenti et al., 2007 [34], in this study a serial Spectroscopic MRI studies was conducted on 21 patients with the histologic diagnosis of LGGs to evaluate a new tumour marker. The study identified NAA/Cho as the best marker of tumour progression before therapy, with a sensitivity of $53.9 \%$.

Danchaivijitr et al., 2008 [22] Longitudinal MRI study was conducted on 21 treated LGGs' patients to establish the correlation between rCBV and time of malignant transformation. At the point of study entry transformers and nontransformers had relatively similar baseline rCBV (1.93 vs 1.31); however, the increase of rCBV (up to 5.36) was notice during the course of MRI follow-up in transformers, whereas in non-transformers, there was no significant change in rCBV (1.53) over the period of 23 months.

Rees et al., 2009 [31] this is a longitudinal study of 27 untreated LGGs' patients who underwent a serial conventional MRI examination in order to determine the relationship of tumour volume and growth rate with the malignant transformation. At study entry, the tumour volume of the 9NT (non-transformers) was (57 ml, 95\% CI 35-80 ml) which had not undergone significant increase over the study period, with the average annual growth rate of $16 \%$ (95\% CI 9$23 \%)$. On the other hand, the $18 \mathrm{~T}$ (transformers) with the entry tumour volume of (83 $\mathrm{ml}, 95 \% \mathrm{CI} 70-96 \mathrm{ml})(\mathrm{p}=0.03)$ had undergone significant volume increase, with the average annual growth rate of 26\% (95\% CI 20-31\%) (p=0.046).

Brasil Caseiras et al., 2009 [32], this is a prospective study of histologically proven LGGs who underwent conventional, perfusion-weighted, and diffusion-weighted MR imaging to compare tumour volume, rCBV, and apparent diffusion coefficient(ADC) and short-term changes of these parameters to predict time of malignant transformation. The best predictor of malignant transformation was found to be the tumour growth over the course of 6 months from the study entry. The risk of transformation during the study was 2.10 times higher per each additional SD of tumour growth within 6 months (95\% CI: 1.05, 4.16; P = .03; SD = 6.19 mL).

Caseiras et al. (2010) [7], this is a multi-institution retrospective study of 69 patients with histology confirmation of LGGs. All of the patients underwent dynamic susceptibility contrast-enhancedperfusion MRI with 3 to 6 month followup interval, to detect the role of rCBV in early detection of malignant transformation. The transformer was found to have significantly high baseline rCBV than non-transformers, with the odds ratio of 1.87 (95\% confidence interval: $1.14-$ 3.08).

Hlaihel et al., 2010 [33], this is a longitudinal study of 21 LGGs patients with proven histological diagnosis; all of the patients underwent conventional MRI and MRS and perfusion MRI studies. The first follow-up studies were done after 3 months then twice a year, with the average of 5 MRI studies per patient. The study revealed that, the Cho/Cr ration of 2.4 is associated with $83 \%$ chances of anaplastic transformation in an average delay of 15.6 months, with the sensitivity and specificity of $80 \%$ and $94 \%$ respectively.

\subsection{Methodological quality of included studies}

The risk of bias of eight (8) included studies has been assessed to be low or unclear. There is low risk of bias in the patients' selection, reference standard and flow and timing in all of the included studies. However, some of the 
parameters such as blinding of the MRI interpreting physician to the result of the reference standard were unclear in some studies. The summary is shown in Figure 2 and the quality assessment result is shown in Figure 3.

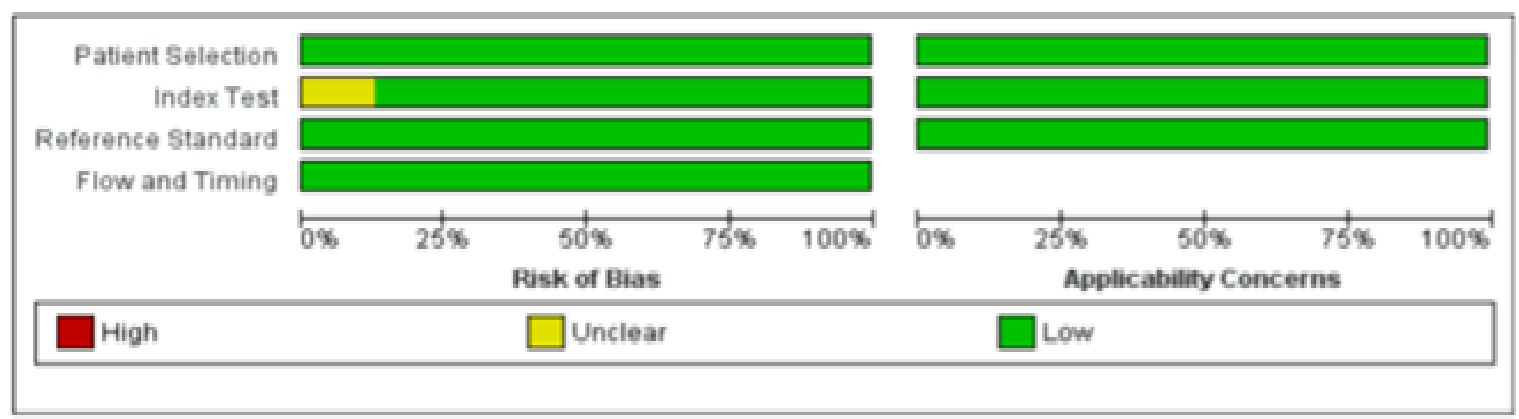

Figure 2 Risk of bias and applicability concerns graph: Review author's judgments about each domain presented as percentages across included studies

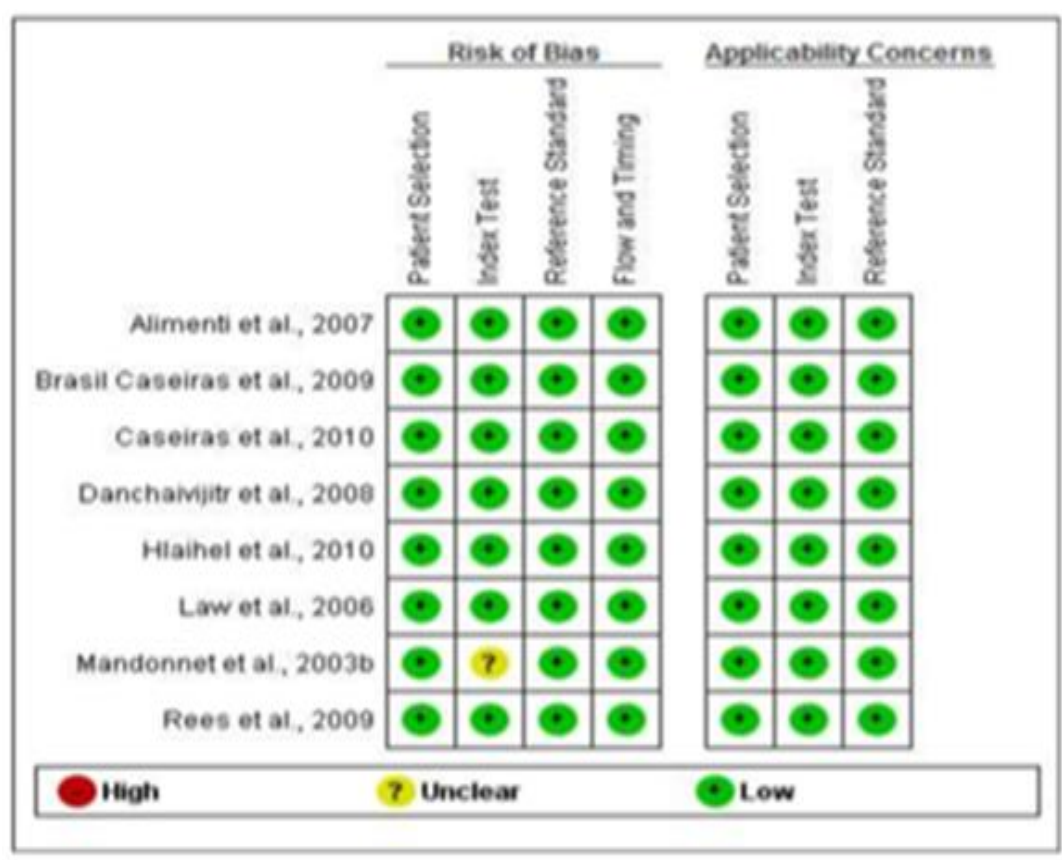

Figure 3 Risk of bias and applicability concerns summary: Review author's judgments about each domain for each included study

The spectrum of participants (item1) was judged as representative in all of the included studies. The setting was secondary or tertiary care and the patients had presented with a confirmed diagnosis of LGGs by histology or immunohistochemistry. The answers for the reference standard (item 2) and avoided partial verification (item 4) and for 'incorporation avoided' (item 6) were 'Yes' (no bias) for all included studies. Learning curve and training for the index (items 12) were reported to be yes, whereas the learning curve and training for the reference standard readers (items 13) were unclear in all of the included studies. More than 50\% of the included studies poorly described the following QUADAS items: The period between reference standard and index test (item 3), differential verification bias (item5), index test results blinded (item 7), reference standard results blinded (item8), relevant clinical information (item9). The remaining QUADAS items are well described in 50\% to 75\% of included studies: un interpretable results reported (item 10), withdrawals explained (item 11) and index test criteria for a positive result (item14).the details are presented in Appendix 2 and the other details of included studies are summarized in Table 1. 
Table 1 Summary of the results of the included studies

\begin{tabular}{|c|c|c|c|c|c|c|c|c|}
\hline Study & $\begin{array}{l}\text { (Danchaivijitr } \\
\text { et al., 2008) } \\
{[22]}\end{array}$ & $\begin{array}{l}\text { (Brasil } \\
\text { Caseiras et al., } \\
\text { 2009) [32] }\end{array}$ & $\begin{array}{l}\text { (Caseiras et } \\
\text { al., 2010) [7] }\end{array}$ & $\begin{array}{l}\text { (Rees et al., } \\
\text { 2009) [31] }\end{array}$ & $\begin{array}{l}\text { (Hlaihel et al., } \\
\text { 2010) [33] }\end{array}$ & $\begin{array}{l}\text { (Law et al., 2006) } \\
\text { [30] }\end{array}$ & $\begin{array}{l}\text { (Mandonnet et } \\
\text { al., 2003b) [24] }\end{array}$ & $\begin{array}{l}\text { (Alimenti et al., } \\
\text { 2007) [34] }\end{array}$ \\
\hline Study design & Prospective & Prospective & Retrospective & Prospective & Prospective & Retrospective & Retrospective & Prospective \\
\hline $\begin{array}{l}\text { Duration of } \\
\text { the study }\end{array}$ & $\begin{array}{lr}\text { August } 2000 \\
\text { and August } \\
2002\end{array}$ & $\begin{array}{l}\text { August } 2000 \\
\text { and } \\
\text { September } \\
2006 .\end{array}$ & 1963 to 2009 & $\begin{array}{l}\text { July } 2000 \text { to } \\
\text { October } 2003\end{array}$ & $\begin{array}{lr}\text { March } & 2005 \\
\text { and April } 2008\end{array}$ & & 1989 t0 2001 & $\begin{array}{l}\text { January } 1998 \text { and } \\
\text { December } 2003\end{array}$ \\
\hline $\begin{array}{l}\text { Population } \\
\text { samples }\end{array}$ & 21 & 34 & 69 & 34 & 21 & 189 & 27 & 21 \\
\hline $\begin{array}{l}\text { Target } \\
\text { condition }\end{array}$ & $\begin{array}{l}\text { Low grade } \\
\text { Gliomas }\end{array}$ & $\begin{array}{l}\text { Low-Grade } \\
\text { Gliomas }\end{array}$ & $\begin{array}{l}\text { Low-Grade } \\
\text { Gliomas }\end{array}$ & $\begin{array}{l}\text { Low-grade } \\
\text { Gliomas }\end{array}$ & $\begin{array}{l}\text { Low-Grade } \\
\text { Gliomas }\end{array}$ & $\begin{array}{l}\text { Low-Grade } \\
\text { Gliomas }\end{array}$ & $\begin{array}{l}\text { Low-Grade } \\
\text { Gliomas }\end{array}$ & $\begin{array}{l}\text { Low-Grade } \\
\text { Gliomas }\end{array}$ \\
\hline Index test (s) & $\begin{array}{l}\text { Conventional } \\
\text { and Dynamic } \\
\text { susceptibility- } \\
\text { weighted MRI }\end{array}$ & $\begin{array}{l}\text { conventional, } \\
\text { perfusion- } \\
\text { weighted and } \\
\text { diffusion- } \\
\text { weighted } \\
\text { imaging }\end{array}$ & $\begin{array}{l}\text { Conventional } \\
\text { and Dynamic } \\
\text { susceptibility- } \\
\text { weighted MRI }\end{array}$ & $\begin{array}{l}\text { The } \\
\text { conventional } \\
\text { MRI }\end{array}$ & $\begin{array}{l}\text { conventional, } \\
\text { perfusion, and } \\
\text { spectroscopy } \\
\text { MRI }\end{array}$ & $\begin{array}{l}\text { Conventional, } \\
\text { Dynamic } \\
\text { Susceptibility- } \\
\text { weighted } \\
\text { Contrast- } \\
\text { enhanced } \\
\text { Perfusion } \quad \text { MR } \\
\text { Imaging1 }\end{array}$ & $\begin{array}{l}\text { Conventional } \\
\text { Magnetic } \\
\text { Resonance } \\
\text { Imaging }\end{array}$ & $\begin{array}{l}\text { Magnetic } \\
\text { Resonance } \\
\text { Spectroscopy }\end{array}$ \\
\hline $\begin{array}{l}\text { Parameters } \\
\text { measured }\end{array}$ & $\mathrm{rCBV}$ & $\mathrm{rCBV}$ & $\mathrm{rCBV}$ & $\begin{array}{l}\text { tumour } \\
\text { volumes and } \\
\text { growth rates }\end{array}$ & $\begin{array}{l}\text { choline, rCBV, } \\
\text { and tumor } \\
\text { growth rate }\end{array}$ & $\mathrm{rCBV}$ & Tumour Grouth & $\begin{array}{l}\text { NAA/Cho Cho/Cr } \\
\text { Myo/Cr Lipids }\end{array}$ \\
\hline $\begin{array}{l}\text { Follow-up } \\
\text { Duration }\end{array}$ & 36 Months & 30 months & $\mathrm{N} / \mathrm{A}$ & 46 Months & & 119 Months & 88 Months & Not given \\
\hline $\begin{array}{l}\text { Treatment } \\
\text { During } \\
\text { studies }\end{array}$ & $\begin{array}{l}\text { Anti-epileptic } \\
\text { drugs }\end{array}$ & $\begin{array}{l}\text { Anti-epileptic } \\
\text { drugs, Surg, } \\
\text { Rad\&Chem }\end{array}$ & $\begin{array}{l}\text { Surgery, } \\
\text { Radiotherapy } \\
\text { and } \\
\text { chemotherap } \\
\text { y }\end{array}$ & $\begin{array}{l}\text { Anti-epileptic } \\
\text { drugs }\end{array}$ & $\begin{array}{l}\text { Anti-epileptic/ } \\
\text { surgery,chemo } \\
\& \\
\text { radiotherapy }\end{array}$ & No & $\begin{array}{l}\text { Radiotherapy, } \\
\text { chemo and } \\
\text { Surgery }\end{array}$ & $\begin{array}{l}\text { Radiochemothera } \\
\text { py/Surgery }\end{array}$ \\
\hline
\end{tabular}


GSC Advanced Research and Reviews, 2020, 05(03), 014-029

\begin{tabular}{|c|c|c|c|c|c|c|c|c|}
\hline $\begin{array}{l}\text { Follow-up } \\
\text { Imaging }\end{array}$ & 6 monthly & 6 Monthly & $\begin{array}{l}3 \text { monthly/6 } \\
\text { Monthly }\end{array}$ & 6 Monthly & $\begin{array}{l}3 \text { Month then } 6 \\
\text { monthly }\end{array}$ & 3 monthly & Nil & Nil \\
\hline $\begin{array}{l}\text { Main } \\
\text { predictor }\end{array}$ & $\begin{array}{l}\text { Tumour } \\
\text { volume }\end{array}$ & $\begin{array}{l}\text { Tumour } \\
\text { Volume }\end{array}$ & $\mathrm{rCBV}$ & $\begin{array}{l}\text { Tumour } \\
\text { volumes }\end{array}$ & $\begin{array}{l}\text { choline/creati } \\
\text { ne }\end{array}$ & rCBV & $\begin{array}{l}\text { Mean Tumour } \\
\text { diameter }\end{array}$ & NAA/Cho \\
\hline $\begin{array}{l}\text { Reference } \\
\text { standard }\end{array}$ & Histology & Histology & Histology & Histology & Histology & Histology & Histology & Histology \\
\hline $\begin{array}{l}\text { Sensitivity } \\
(95 \% \mathrm{CI})\end{array}$ & & $83.30 \%$ & & & $80 \%$ & & & $57.10 \%$ \\
\hline $\begin{array}{l}\text { Specificity } \\
\text { (95\% CI) }\end{array}$ & & $83.30 \%$ & & & $86 \%$ & & & $100 \%$ \\
\hline TP & 5 & & & 9 & & & & \\
\hline FP & 0 & & & 1 & & & & \\
\hline TN & 2 & & & 0 & & & & \\
\hline FN & 8 & & & 9 & & & & \\
\hline
\end{tabular}




\subsection{Findings}

The review is based on the qualitative assessment of individual studies as only few relevant studies were identified. Moreover, each study used different methodology and MRI parameters. The summary of the characteristics of included studies is shown in table 1. There was no any anti-cancer treatments administered to any of the patients in the included studies, before the study period. However, only 14 patients have been reported to have partial resection [33] before their recruitment into the study. In four of the studies [22, 32, 31,33], patients presented with seizures and therefore were treated with anti-epileptic drugs. However, in $[33,32]$ treatment such as surgery, radiotherapy and chemotherapy or combined treatments have been instituted in some patients based on the patients' needs. Likewise, the other four studies $[34,24,7]$ have also reported commencement of treatments to some patients at some point during the study period. Only one study [30] has not reported any treatment during the study period. [33]. Four studies [22, 32, 7, 35] measured relative cerebral blood volume (rCBV) to identify its correlation with LGGs progression to HGGs. A combination of tumour volumes and growth rates were measured in [31]. Additionally, choline, rCBV, and tumour growth rate are considered and measured in [33, 24]. Tumour Growth, NAA/Cho, Cho/Cr (choline/creatine), Myo/Cr (myoanositol/creatine) and Lipids have been measured in [34].The follow-up imaging was organized between 3 and 6 monthly except in three studies [35,34,24], in which the period of follow-up has not been reported. In all of the included studies patients were classified into two groups; transformers (Those that their lesions transformed to HGGs at some point during study periods) and non-transformers (those that remain stable without transformation during the study periods). Two studies $[30,7]$ identified rCVB as the main predictor while other three studies $[22,32,31]$ identified tumour volume as the main predictor. Whereas, two studies [33,34] considered choline as the main predictor of malignant transformation. The remaining study [24] identified Mean tumour diameter as the main predictor of malignant transformation.

It has been reported in [7] that, there is negative association between $\mathrm{rCBV}$ and the time of malignant progression with $(\mathrm{p}=0.0059)$, Transformers have high baseline $\mathrm{rCBV}(\geq 1.75)$ than Non-transformers $(<1.75)$. This relationship is consistent with the report in [30,32, 22, 24].The tumour volume is reported to be smaller in non-transformers than the transformers [31], in Nine (9) Non-transformers (57 ml, 95\% CI 35-80 ml) and in eighteen (18) Transformers (83 ml, 95\% CI 70-96 ml) ( $\mathrm{p}=0.03)$ [31]. The same study indicated that there is also slower annual growth rate in nontransformers than transformers. Choline/ Creatine $(\mathrm{Cho} / \mathrm{Cr}$ ) has been reported to be a significant predictive indicator of malignant transformation in a study done by [33].

\section{Discussion}

The main aim of this review is to identify and summarize the available MRI imaging technique(s), that can be used in predicting the early malignant transformation of the LGGs and to recognize their effectiveness in identifying these transformations. Meta-analysis was not attempted in this review due to the fewer number of studies as well as the heterogeneity of the methodologies and the techniques used in the included studies. Therefore, there is no overall figure to suggest the sensitivity and specificity of Multi-parametric MRI imaging in early detection of malignant transformation of LGGs. However, the overall impression of the individual studies was identified. The result of this review shows that different MRI techniques use different parameters in detecting the early malignant transformation. Prospective and retrospective studies (Eight) had been used in this review, with 313 participants. There are relatively standard image acquisitions in all the included studies in this review. However, there is different level of expertise in the people interpreting the results, which may significantly affect the results of the studies. The relevancy of Multi-parametric MRI in early detection of malignant transformation of LGGs has been identified with different level of effectiveness between MRI techniques and parameters.

\subsection{Strengths and weaknesses of the review}

Focus has been made on studies that evaluate different MRI parameters versus reference standard in prediction of malignant transformation of LGGs in the same patient. Measure electronic databases have been searched to identify relevant studies and studies have been carefully selected and assessed for inclusion in the review.

All of the patients included the review had no any previous form of anti-cancer treatments and only fourteen (14) patients had partial resection. However, many patients receive one or the other form of treatment during the study period as a result of tumour progression or clinical sign of malignant transformation. The risk of having structural damage to the brain as a result of treatment is high; this will go a long way in increasing errors in reporting of the MRI studies. The example of the adverse effects of treatment that may affect the actual result of the MRI is radiotherapy and chemotherapy induced-necrosis of the brain $[36,37]$. 
The studies included in this review are relatively small number; they are also associated with incomplete presentation of study data and results and relatively small sample size. These added together have contributed significantly in the limitations of this review.

Meta-analysis could not be used in this review due to the small number of studies and the lack of sufficient data to construct two-by-two contingency table. This has done a significant negative impact on the precision of this review. Cost effectiveness of MRI in early prediction of malignant transformation has not been assessed.

\section{Conclusion}

Tumour Growth rate, Relative cerebral blood volume and Choline have proven to be a useful predictor of early malignant transformation of LGGs. Based on the findings in the included studies, MRI has a very important role in the early prediction of malignant transformation of LGGs. This is a pointer that, MRI techniques could be used as the imaging modality of choice in monitoring the progress of LGGs, this possibility maybe confirmed by conducting studies that involve more number of participants. There is need for high quality large scale, prospective studies on the role of multiparametric MRI studies in early prediction of malignant transformation of LGGs. Furthermore, meta-analysis of these studies is highly recommended.

\section{Compliance with ethical standards}

\section{Acknowledgments}

I would like to thank Dr. Steven Sourbron for given his time and advice to support this project. I would also like to thank my family for their invaluable support. I also want to extend my sincere appreciation to the Sokoto State Scholarship Board for the financial support.

\section{Disclosure of conflict of interest}

There is no conflict of interest

\section{References}

[1] Grier JT, Batchelor T. Low-Grade Gliomas in Adults. The Oncologist. 2006; 11: 681-693.

[2] Brodal P. Central Nervous System Structure And Function. 2010.

[3] Smith C, Ironside JW. Diagnosis and pathogenesis of gliomas. Current Diagnostic Pathology. 2007; 13: $180-192$.

[4] Sanai N, Chang S, Berger MS. Low-Grade Gliomas In Adults. Journal Of Neurosurgery. 2011; 115: $948-965$.

[5] Kao HW, Chiang SW, Chung HW, Tsai FY, Chen CY. Advanced MR imaging of gliomas: an update. BioMed research international. 2013; 970586.

[6] Kros JM. WHO Guidelines for Diagnosis of Glial Tumours: What Is Old and What Is New? European Association of NeuroOncology Magazine. 2011; 1: 9-12.

[7] Caseiras GB, Chheang S, Babb J, Rees JH, Pecerrelli N, Tozer DJ, Benton C, Zagzag D, Johnson G, Waldman AD, Jäger HR, Law M. Relative cerebral blood volume measurements of low-grade gliomas predict patient outcome in a multi-institution setting. European Journal of Radiology. 2010; 73: 215-220.

[8] Soffietti R, Baumert BG, BelloL, Von Deimling A, Duffau H, Frénay M, Grisold W, Grant R, Graus F, Hoang-Xuan K, Klein M, Melin B, Rees J, Siegal T, Smits A, Stupp R, Wick W. Guidelines on management of low-grade gliomas: report of an EFNS-EANO* Task Force. European Journal of Neurology. 2010; 17: 1124-1133.

[9] Pouratian N, Schiff D. Management of low-grade glioma. Current neurology and neuroscience reports. 2010; 10: 224-231.

[10] Mandonnet E, Delattre JY, Tanguy ML, Swanson KR, Carpentier AF, Duffau H, Cornu P, Van Effenterre R, Alvord EC, Capelle L. Continuous growth of mean tumor diameter in a subset of grade II gliomas. Annals of neurology. 2003; 53: 524-528.

[11] Smith JS, Chang EF, Lamborn KR, Chang SM, Prados MD, Cha S, et al. Role of extent of resection in the long-term outcome of low-grade hemispheric gliomas. Journal of Clinical Oncology. 2008; 26(8):1338-45. 
[12] Soffietti R, Baumert B, Bello L, Von Deimling A, Duffau H, Frénay M, Grisold W, Grant R, Graus F, Hoang-Xuan K. Guidelines on management of low-grade gliomas: report of an EFNS-EANO* Task Force. European journal of neurology. 2010; 17: 1124-1133.

[13] Hoang-Xuan K, Capelle L, Kujas M, Taillibert S, Duffau H, Lejeune J, Polivka M, CrinièreE, Marie Y, Mokhtari K, Carpentier AF, Laigle F, Simon JM, Cornu P, Broët P, Sanson M, Delattre JY. Temozolomide As Initial Treatment for Adults With Low-Grade Oligodendrogliomas or Oligoastrocytomas and Correlation With Chromosome 1p Deletions. Journal of Clinical Oncology. 2004; 22: 3133-3138.

[14] Blonski M, Taillandier L, Herbet G, Maldonado I, Beauchesne P, Fabbro M, Campello C, Gozé C, Rigau V, MoritzGasser S, Kerr C, Rudà R, Soffietti R, Bauchet L, Duffau H. Combination of neoadjuvant chemotherapy followed by surgical resection as a new strategy for WHO grade II gliomas: a study of cognitive status and quality of life. Journal of Neuro-Oncology. 2012; 106: 353-366.

[15] Klein M, Engelberts NH, Van Der Ploeg HM, Kasteleijn-Nolst Trenité DG, Aaronson NK, Taphoorn MJ, Baaijen H, Vandertop WP, Muller M, Postma TJ. Epilepsy in low-grade gliomas: The impact on cognitive function and quality of life. Annals of neurology. 2003; 54: 514-520.

[16] Sahin N, Melhem ER, Wang S, Krejza J, Poptani H, Chawla S, Verma G. Advanced MR imaging techniques in the evaluation of nonenhancing gliomas: Perfusion-weighted imaging compared with proton magnetic resonance spectroscopy and tumor grade. Neuroradiology Journal. 2013; 26: 531-541.

[17] Chawalparit O, Sangruchi T, Witthiwej T, Sathornsumetee S, Tritrakarn S, Piyapittayanan S, Chaicharoen P, Direksunthorn T, Charnchaowanish P. Diagnostic performance of advanced MRI in differentiating high-grade from low-grade gliomas in a setting of routine service. Journal of the Medical Association of Thailand =Chotmaihet thangphaet. 2013; 96: 1365-1373.

[18] Schmainda KM, Rand SD, Joseph AM, Lund R, Ward BD, Pathak AP, Ulmer JL, Baddrudoja MA, Krouwer HG. Characterization of a first-pass gradient-echo spin-echo method to predict brain tumor grade and angiogenesis. American Journal of Neuroradiology. 2004; 25: 1524-1532.

[19] Karatağ O, Karată̆ GY, Uysal E, Can SM, Ertürk M, Başak M. Can Magnetic Resonance Spectroscopy Adequately Differentiate Neoplastic From Non-Neoplastic And Low-Grade From High-Grade Lesions In Brain Masses? Marmara Medical Journal. 2010; 23: 326-338.

[20] Mcknight TR, Lamborn KR, Love TD, Berger MS, Chang S, Dillon WP, Bollen A, Nelson SJ. Correlation of magnetic resonance spectroscopic and growth characteristics within Grades II and III gliomas. Journal of neurosurgery. 2007; 106: 660-666.

[21] Bisdas S, Kirkpatrick M, Giglio P, Welsh C, Spampinato MV, Rumboldt Z. Cerebral Blood Volume Measurements by Perfusion-Weighted MR Imaging in Gliomas: Ready for Prime Time in Predicting Short-Term Outcome and Recurrent Disease? American Journal of Neuroradiology. 2009; 30: 681-688.

[22] Danchaivijitr N, Waldman AD, Tozer DJ, Benton CE, Brasil Caseiras G, Tofts PS, Rees JH, Jäger HR. Low-Grade Gliomas: Do Changes in rCBV Measurements at Longitudinal Perfusion-weighted MR Imaging Predict Malignant Transformation? Radiology. 2008; 247: 170-178.

[23] Majchrzak K, Kaspera W, Bobek-Billewicz B, Hebda A, Stasik-Pres G, Majchrzak H, Ladzinski P. The assessment of prognostic factors in surgical treatment of low-grade gliomas: a prospective study. Clin Neurol Neurosurg. 2012;114: 1135-44.

[24] Mandonnet E, Delattre JY, Tanguy ML, Swanson KR, Carpentier AF, Duffau H, Cornu P, Van Effenterre R, Alvord EC, Capelle L. Continuous growth of mean tumor diameter in a subset of grade II gliomas. Annals of Neurology. 2003; 53: 524-528.

[25] Klein M, Heimans J, Aaronson N, Van Der Ploeg H, Grit J, Muller M, Postma T, Mooij J, Boerman R,Beute G. Effect of radiotherapy and other treatment-related factors on mid-term to long-term cognitive sequelae in low-grade gliomas: a comparative study. The lancet. 2002;360: 1361-1368.

[26] Revman RM. Review Manager (RevMan) [Computer program]. Version 5.0. Copenhagen: The Nordic Cochrane Centre. The Cochrane Collaboration. 2003.

[27] Higgins Jpt GSE. Cochrane Handbook for Systematic Reviews of Interventions Version 5.0.2 [updated September 2009]. The Cochrane Collaboration. 2009.

[28] Whiting P, RA, Reitsma Jb, Bossuyt Pm, Kleijnen J. The development of QUADAS: a tool for the quality assessment of studies of diagnostic accuracy included in systematic reviews. BMC Medical Research Methodology. 2003 ; $3: 25$. 
[29] Reitsma Jb, RA, Whiting P, Vlassov Vv, Leeflang, Mmg DJ. Chapter 9: Assessing methodological quality. Deeks JJ, Bossuyt PM, Gatsonis C (editors),. Cochrane Handbook for Systematic Reviews of Diagnostic Test Accuracy Version 1.0.0. The Cochrane Collaboration. 2009.

[30] Law M, Oh S, Babb JS, Wang E, Inglese M, Zagzag D, Knopp EA, Johnson G. Low-Grade Gliomas: Dynamic Susceptibility-weighted Contrast-enhanced Perfusion MR Imaging-Prediction of Patient Clinical Response. Radiology. 2006; 238:658-667.

[31] Rees J, Watt H, Jager HR, Benton C, Tozer D, Tofts P, Waldman A. Volumes and growth rates of untreated adult low-grade gliomas indicate risk of early malignant transformation. Eur J Radiol. 2009; 72: 54-64.

[32] Brasil Caseiras G, Ciccarelli O, Altmann DR, Benton CE, Tozer DJ, Tofts PS, Yousry TA, Rees J, Waldman AD, Jäger HR. Low-Grade Gliomas: Six-month Tumor Growth Predicts Patient Outcome Better than Admission Tumor Volume, Relative Cerebral Blood Volume, and Apparent Diffusion Coefficient. Radiology. 2009; 253: 505-512.

[33] Hlaihel C, Guilloton L, Guyotat J, Streichenberger N, Honnorat J, Cotton F. Predictive value of multimodality MRI using conventional, perfusion, and spectroscopy MR in anaplastic transformation of low-grade oligodendrogliomas. Journal of Neuro-Oncology. 2010; 97: 73-80.

[34] Alimenti A, Delavelle J, Lazeyras F, Yilmaz H, Dietrich PY, De Tribolet N, Lövblad KO. Monovoxel 1H magnetic resonance spectroscopy in the progression of gliomas. European neurology. 2007;58:198-209.

[35] Law M, Yang S, Wang H, Babb JS, Johnson G, Cha S, Knopp EA, Zagzag D. Glioma Grading: Sensitivity, Specificity, and Predictive Values of Perfusion MR Imaging and Proton MR Spectroscopic Imaging Compared with Conventional MR Imaging. American Journal of Neuroradiology. 2003; 24:1989-1998.

[36] Kumar AJ, Leeds NE, Fuller GN, Van Tassel P, Maor MH, Sawaya RE, Levin VA. Malignant Gliomas: MR Imaging Spectrum of Radiation Therapy- and Chemotherapy-induced Necrosis of the Brain after Treatment. Radiology. 2000; $217: 377-384$.

[37] Surma-Aho O, Niemelä M, Vilkki J, Kouri M, Brander A, Salonen O, Paetau A, Kallio M, J Pyykkönen L, Jääskeläinen J. Adverse long-term effects of brain radiotherapy in adult low-grade glioma patients. Neurology. 2001; 56: 12851290.

\section{Appendices}

Appendix 1. Search strategies

MEDLINE search strategy

- Magnetic Resonance Imaging/

- Nuclear magnetic resonance imaging\$

- ((magnetic resonance or MR or MRI or NMR) adj5 (glioma\$)).tw.

- Diffusion-weighed MRI\$

- Perfusion MRI\$

- Molecular MRI\$

- MRI Spectroscopy\$

- Blood-Oxygenation-level dependent\$

- Dynamic susceptibility contrast MRI\$

- 1 or 2 or 3 or 4 or 5 or 6 or 7 or 8 or 9

- Low-grade Gliomas\$

- Gliomas\$

- Primary brain tumo?r\$

- 11 or 12 or 13

- sensitiv* $^{*}$

- $\quad$ sensitivity and specificity

- diagnosis

- diagnos*

- diagnostic*

- $\quad$ specificity.tw.

- $\quad$ specificity

- $\quad$ sensitiv:.mp. 
- predictive value:.mp.

- predictive value of tests

- accurac:.tw.

- accuracy*

- (predictive adj5 value\$).tw.

- exp diagnostic errors/

- ((false adj positive\$) or (false adj negative\$)).tw.

- (observeradj variation\$).tw.

- (rocadj curve\$).tw.

- (likelihood adj3 ratio\$).tw.

- likelihood function/

- 15 or 16 or 17 or 18 or 19 or 20 or 21 or 22 or 23 or 24 or 25 or 26 or 27 or 28 or 29 or 30 or 31 or 32 or 33

- 10 and 14 and 33

\section{EMBASE search strategy}

- magnetic resonance angiography/

- Nuclear magnetic resonance imaging/

- ((magnetic resonance or MR or MRI or NMR) adj5 (Low-grade Gliomas\$ or gliomas\$)).tw.

- Diffusion-weighted MRI/

- Diffusion-weighted MRI\$

- Perfusion MRI/

- $\quad$ Perfusion MRI\$

- Molecular MRI\$

- MRI spectroscopy\$

- Blood-Oxygenation-level dependent/

- Blood-Oxygenation-level dependent\$

- Dynamic susceptibility contrast MRI/

- Dynamic susceptibility contrast MRI\$

- 1 or 2 or 3 or 4 or 5 or 6 or 7 or 8 or 9 or 10 or 11 or 12 or 13

- Low-grade Gliomas\$

- Gliomas\$

- Primary brain tumo?r/

- Primary brain tumo?r\$

- 15 or 16 or 17 or 18

- di.fs.

- sensitiv:.tw.

- predict:.tw.

- specificity.tw.

- receiver operating characteristic/

- diagnostic accuracy.sh.

- diagnostic.tw.

- diagnostic accuracy/

- exp diagnostic error/

- observer variation/

- limit of detection/

- diagnostic test accuracy study.sh.

- $\quad$ predictive adj3 value\$

- false adj positive\$

- false adj negative $\$$

- observer variation\$

- roc adj curve\$

- likelihood adj3 ratio\$

- 20 or 21 or 22 or 23 or 24 or 25 or 26 or 27 or 28 or 29 or 30 or 31 or 32 or 33 or 34 or 35 or 36 or 37

- 19 and 14 and 38 
Appendix 2. Assessment of methodological quality: QUADAS and additional items

\begin{tabular}{|c|c|c|}
\hline Item Definition & Item Question & Assessment \\
\hline $\begin{array}{l}\text { Representative } \\
\text { spectrum }\end{array}$ & $\begin{array}{l}\text { Was the spectrum of patients } \\
\text { representative of the patients who will } \\
\text { receive the test in practice }\end{array}$ & $\begin{array}{l}\text { Yes:(a) the setting was secondary or tertiary care } \\
\text { AND (b) the population was patients with Low-Grade } \\
\text { Gliomas (c) the study was prospective or } \\
\text { retrospective (d) recruitment was consecutive } \\
\text { Unclear: if insufficient information was given on the } \\
\text { setting, selection criteria, or selection procedure to } \\
\text { make a judgment } \\
\text { No:(a) recruitment was not consecutive }\end{array}$ \\
\hline $\begin{array}{l}\text { Acceptable } \\
\text { reference standard }\end{array}$ & $\begin{array}{l}\text { Isthereferencestandardlikelytoclassify } \\
\text { the target condition correctly? }\end{array}$ & $\begin{array}{l}\text { Yes: if the reference standard was Histology Unclear: } \\
\text { ifthetarget condition was only brain tumour not Low- } \\
\text { Grade Gliomas } \\
\text { No: not applicable }\end{array}$ \\
\hline $\begin{array}{l}\text { Acceptable delay } \\
\text { between tests }\end{array}$ & $\begin{array}{l}\text { Is the time period between reference } \\
\text { standard and index test short enough } \\
\text { to be reasonably sure that the target } \\
\text { condition did not change between the } \\
\text { two tests? }\end{array}$ & $\begin{array}{l}\text { Yes: if the average interval between reference } \\
\text { standard and index test was one month or less } \\
\text { Unclear: if the interval between tests was not clearly } \\
\text { reported } \\
\text { No: if the average interval between reference } \\
\text { standard and index test was longer than one month }\end{array}$ \\
\hline $\begin{array}{l}\text { Partial verification } \\
\text { avoided }\end{array}$ & $\begin{array}{l}\text { Did the whole sample or a random } \\
\text { selection of the sample, receive } \\
\text { verification using the intended } \\
\text { reference standard? }\end{array}$ & $\begin{array}{l}\text { Yes: If all patients who received the index test went } \\
\text { on to receive verification of their disease status using } \\
\text { a reference standard (Score 'Yes' even if different } \\
\text { reference tests were used) } \\
\text { Unclear: if insufficient information was given on } \\
\text { relation of index test and reference standard } \\
\text { No: if not all the patients who received the index test } \\
\text { underwent a reference standard to verify their true } \\
\text { disease status }\end{array}$ \\
\hline $\begin{array}{l}\text { Differential } \\
\text { verification bias }\end{array}$ & $\begin{array}{l}\text { Did patients receive the same } \\
\text { reference standard irrespective of the } \\
\text { index test result? }\end{array}$ & $\begin{array}{l}\text { Yes: if all patients received the same reference } \\
\text { standard, regardless of the result of their index test } \\
\text { Unclear: If it is unclear whether different reference } \\
\text { standards were used } \\
\text { No: if the result of the index test influenced the } \\
\text { choice of the reference standard }\end{array}$ \\
\hline Incorporation bias & $\begin{array}{l}\text { Was the reference standard } \\
\text { independent of the index test (i.e. the } \\
\text { index test did not form part of the } \\
\text { reference standard) }\end{array}$ & $\begin{array}{l}\text { Should be considered 'Yes' for all studies because the } \\
\text { index test is not part of the reference standard }\end{array}$ \\
\hline $\begin{array}{l}\text { Index test results } \\
\text { blinded }\end{array}$ & $\begin{array}{l}\text { Were the index test results interpreted } \\
\text { without knowledge of the results of the } \\
\text { reference standard? }\end{array}$ & $\begin{array}{l}\text { Yes: if the person undertaking the index test was } \\
\text { blinded to the results of the standard reference } \\
\text { Unclear: if insufficient information was given on } \\
\text { independent or blind assessment of the index test } \\
\text { No: if the results of the reference tests were known } \\
\text { to the person undertaking the index tests }\end{array}$ \\
\hline $\begin{array}{l}\text { Reference standard } \\
\text { results blinded }\end{array}$ & $\begin{array}{l}\text { Were the reference standard results } \\
\text { interpreted without knowledge of the } \\
\text { results of the index test? }\end{array}$ & $\begin{array}{l}\text { Yes: if the reference standard results were } \\
\text { performed blind to the results of the index test } \\
\text { Unclear: if insufficient information was given on } \\
\text { independent or blind assessment of the reference } \\
\text { standard }\end{array}$ \\
\hline
\end{tabular}




\begin{tabular}{|c|c|c|}
\hline & & $\begin{array}{l}\text { No: if the results of the index tests were known to the } \\
\text { person interpreting the reference tests }\end{array}$ \\
\hline $\begin{array}{l}\text { Relevant clinical } \\
\text { information }\end{array}$ & $\begin{array}{l}\text { Were the same clinical data available } \\
\text { when test results were interpreted as } \\
\text { would be available when the test is } \\
\text { used in practice? }\end{array}$ & $\begin{array}{l}\text { Yes: if clinical data would normally be available when } \\
\text { the test is interpreted in practice and similar data } \\
\text { were available when interpreting the index test in } \\
\text { the study } \\
\text { Unclear: if insufficient information was given to } \\
\text { explain which clinical information was available at } \\
\text { the time of assessment No: if clinical data were not } \\
\text { available when index test(s) was(were) interpreted }\end{array}$ \\
\hline $\begin{array}{l}\text { Uninterpretable } \\
\text { results reported }\end{array}$ & $\begin{array}{l}\text { Were un interpretable/intermediate } \\
\text { test results reported? }\end{array}$ & $\begin{array}{l}\text { Yes: If the number of uninterpretable test results is } \\
\text { stated, or if the number of results reported agrees } \\
\text { with the number of patients recruited (indicating no } \\
\text { uninterpretable test results) Unclear: if insufficient } \\
\text { information was given to permit judgement } \\
\text { No: If it states that uninterpretable test results } \\
\text { occurred or were excluded and does not report how } \\
\text { many }\end{array}$ \\
\hline $\begin{array}{l}\text { Withdrawals } \\
\text { explained }\end{array}$ & $\begin{array}{l}\text { Were withdrawals from the study } \\
\text { explained? }\end{array}$ & $\begin{array}{l}\text { Yes: if the number and reasons of all withdrawals } \\
\text { from the study were explained(ideally by a flow } \\
\text { chart) or if no participants were excluded from the } \\
\text { analysis Unclear: if insufficient information was } \\
\text { given on the withdrawals } \\
\text { No: if not all withdrawals were explained }\end{array}$ \\
\hline $\begin{array}{l}\text { Learning } \\
\text { curve/training } \\
\text { reported of index } \\
\text { test }\end{array}$ & $\begin{array}{l}\text { Had index test reporter had } \\
\text { appropriate training or experience in } \\
\text { interpreting Neuroimaging? }\end{array}$ & $\begin{array}{l}\text { Yes: (a) if the index test(s) executors were } \\
\text { radiologists } A N D(b) \text { if the tests interpreters had } \\
\text { experience in Neuroimaging } \\
\text { Unclear: if insufficient information was given to } \\
\text { permit judgement } \\
\text { No: (a) if the index test(s) executors were not } \\
\text { radiologists (b) if the tests interpreters had no } \\
\text { experience in Neuroimaging }\end{array}$ \\
\hline $\begin{array}{lr}\text { Learning } & \text { curve } \\
\text { /training } & \text { reported } \\
\text { of } & \text { reference } \\
\text { standard } & \end{array}$ & $\begin{array}{l}\text { Had reference standard test operators } \\
\text { had appropriate training or } \\
\text { experience in shoulder surgery? }\end{array}$ & $\begin{array}{l}\text { Yes: (a) if the results interpreters had experience in } \\
\text { shoulder diseases } \\
\text { Unclear: if insufficient information was given to } \\
\text { permit judgement } \\
\text { No: (a) if the results interpreters had no experience } \\
\text { in shoulder diseases }\end{array}$ \\
\hline $\begin{array}{l}\text { Index test / criteria } \\
\text { for a positive result }\end{array}$ & $\begin{array}{l}\text { Index test criteria for a positive result } \\
\text { reported?? }\end{array}$ & $\begin{array}{l}\text { Yes: (a) if the study provides a clear definition of a } \\
\text { positive test result } \\
\text { Unclear: if insufficient information was given to } \\
\text { permit judgement } \\
\text { No: if no definition is given of a positive test result }\end{array}$ \\
\hline
\end{tabular}

